\title{
Characterizing the microstructural anisotropy of fine-grained phyllosilicate-rich rocks
}

\author{
Rebecca Kühn ${ }^{1}$, Michael Stipp ${ }^{1}$, and Bernd Leiss ${ }^{2}$ \\ ${ }^{1}$ Institut für Geowissenschaften und Geographie, Martin-Luther-Universität, 06120 Halle, Germany \\ ${ }^{2}$ Geowissenschaftliches Zentrum Göttingen, Georg-August-Universität, 37077 Göttingen, Germany
}

Correspondence: Rebecca Kühn (rebecca.kuehn@geo.uni-halle.de)

Published: 10 November 2021

\begin{abstract}
The physical properties of claystones, shales, and slates are highly dependent on the alignment of phyllosilicate minerals. With increasing overburdening, the shape and the crystallographic preferred orientation of these minerals are affected by uniaxial shortening as well as tectonic processes including recrystallization under elevated pressure and temperature conditions. The microstructural anisotropy expressed mainly by the alignment of phyllosilicates significantly predetermines the orientation of fractures, hence the shear strength and stability of clay-rich sediments and rocks. A quantitative analysis of phyllosilicate alignment is therefore essential to evaluate the properties and the mechanical behavior of these rocks. This can be carried out by analyzing the crystallographic preferred orientation (texture).

Although texture analysis is a common tool in geosciences, it becomes more difficult in fine-grained rocks owing to for example particle size, heterogeneity, the polyphase composition, and difficulties in sample preparation. Methods such as electron backscatter diffraction, neutron diffraction, or laboratory X-ray diffraction are restricted with respect to preparation artifacts, sampling size and statistics, water content, etc. To overcome these issues, we successfully apply high-energy X-ray diffraction as available at synchrotron research facilities, e.g., at the German Electron Synchrotron Facility (DESY) in Hamburg, Germany, or the European Synchrotron Research Facility (ESRF) in Grenoble, France. In combination with Rietveld refinement we analyze the bulk texture of phyllosilicate-rich rocks.

Here we present the results of texture analysis from a wide range of these rocks: Pleistocene poorly consolidated mud (rocks), affected only by sedimentation and burial; more highly consolidated but tectonically largely unaffected Jurassic claystone from the Opalinus Formation of the Swabian Alb; Carboniferous shales from the Harz mountains representing low-grade metamorphic and deformed rocks. Our methodical approach to quantifying the microstructural anisotropy using texture analysis in fine-grained rocks allows for the quantification of physical properties resulting from the alignment of phyllosilicates. Furthermore, it enables the prediction of direction-dependent mechanical strength, which is crucial for the establishment of long-term repositories for radioactive waste in shales and claystones.
\end{abstract}

Kurzfassung. Die physikalischen Eigenschaften von Tonsteinen und Tonschiefern sind stark von der Einregelung der Phyllosilikatminerale abhängig. Mit zunehmender Überlagerung werden Formregelung und kristallographische Vorzugsorientierung dieser Minerale durch Kompaktion sowie tektonische Prozesse, einschließlich Rekristallisation unter erhöhten Druck- und Temperaturbedingungen bestimmt. Die mikrostrukturelle Anisotropie, die vor allem durch die Einregelung der Phyllosilikate zum Ausdruck kommt, beeinflusst in erheblichem Ausmaß die Bildung und Ausrichtung von Brüchen und die Festigkeit und Stabilität von tonreichen Gesteinen. Eine quantitative Analyse der Einregelung der Schichtsilikate ist daher unerlässlich, um die mechanischen Eigenschaften dieser Gesteine zu bestimmen. Dazu wird die kristallographische Vorzugsorientierung (Textur) gemessen. Diese ist in den Geowissenschaften eine gängige Methode, die allerdings bei feinkörnigen Phyllosilikat-reichen Gesteinen schwieriger anzuwenden ist, z. B. wegen der Partikelgröße, der Heterogenität, der mehrphasigen Zusammensetzung und der störungsanfälligen Probenpräparation. Methoden 
wie Elektronenrückstreuung, Neutronenbeugung oder Röntgenbeugung im Labor sind hinsichtlich der Präparationsartefakte, der Probengröße und -statistik, des Wassergehalts, usw. eingeschränkt. Um diesen Problemen aus dem Weg zu gehen, setzen wir erfolgreich Hochenergie-Röntgenbeugung ein, wie sie an SynchrotronForschungseinrichtungen verfügbar ist, z. B. am Deutschen Elektronen-Synchrotron (DESY) in Hamburg oder an der European Synchrotron Radiation Facility (ESRF) in Grenoble, Frankreich. Mittels Rietveld-Methode analysieren wir die Gesamttextur von Phyllosilikatreichen Gesteinen.

Wir stellen hier Ergebnisse der Texturanalyse eines breiten Spektrums dieser Gesteine vor: pleistozäne, schwach verfestigte Tone und Tonsteine, die nur dem Einfluss von Sedimentation und Überlagerung unterlagen; stärker verfestigte, aber tektonisch wenig beanspruchte jurassische Tonsteine aus der Opalinuston-Formation der Schwäbischen Alb; karbonische Tonschiefer aus dem Harz, die niedriggradig metamorphe und deformierte Gesteine darstellen. Die Texturanalyse in feinkörnigen Gesteinen ermöglicht die Quantifizierung der physikalischen Eigenschaften, die sich aus der Anordnung der Schichtsilikate ergeben. Außerdem kann daraus die richtungsabhängige mechanische Festigkeit bestimmt werden, die für die Einrichtung von Langzeitlagern für radioaktiven Abfall in Tonsteinen entscheidend ist. 